\title{
Shopsmart: International Market Expansion of an African Retailer
}

\author{
Jay van Wyk \\ Department of Management \& Marketing, Pittsburg State University, Pittsburg Kansas \\ Email: jvanwyk@pittstate.edu
}

\begin{abstract}
The primary subject matter of this case concerns international business focusing on market selection. Secondary issues pertain to the internationalization of an emerging market multinational enterprise; the neglected study of African business; and the global retail sector. The case is appropriate for first year graduate students. The case is designed to be taught in one lecture meeting (two and a half hours) and is expected to require two hours of outside preparation by students.
\end{abstract}

Key Words: Africa, internationalization, retail, market selection, multinational enterprise, South Africa

\section{Case Description}

The primary subject matter of this case concerns international business focusing on market selection. Secondary issues pertain to the internationalization of an emerging market multinational enterprise; the neglected study of African business; and the global retail sector [1,3]. The case is appropriate for first year graduate students. The case is designed to be taught in one lecture meeting (two and a half hours) and is expected to require two hours of outside preparation by students.

\section{Case Synopsis}

Shopsmart, a South African food retailer, faced an important decision in the company's expansion plans. To date, the company has been successful in expanding to neighboring countries, and then further afield, by entering other African countries. CEO Dap Louw felt optimistic that Shopsmart will continue to leverage its competitive advantage as the company plans further international expansion. The company has become, under his leadership and vision, the leading provider of a modern retail shopping experience to an emerging middle class of consumers in African countries. Under CEO Louw's leadership the company successfully targeted African countries, with a faster economic growth rate than South Africa, as the locations of such middle class market segments. For Louw this was a rewarding experience because he identified a trend and then acted to execute the company's expansion into Africa. Shopsmart was successful to position its retail stores in African countries to meet the demand of middle class consumers. Shopsmart provided these consumers with more choices and better quality food products at affordable prices, which local small retailers could not provide. For Louw and Shopsmart, expansion into Africa was a learning experience[7]. The company understood that the African business environment posed many risks. The company encountered challenges with poor infrastructures, confusing regulations, and exchange rate volatility. Shopsmart has worked hard to build legitimacy with local stakeholders. The development of local sourcing for fresh produce has been particularly popular with political authorities and local farmers since agriculture still provides a livelihood to a large part of the population in African countries. However, CEO Louw, indicated that the company will continue to enter African markets with considerable political and economic risk exposure if the opportunities for growth and profitability are favorable.

"If we can't expose ourselves to risk, we shouldn't be in business. We are cowboys from time to time; we do take risks. But we look at our numbers and we are very responsible"

The choice facing Shopsmart is whether to continue its successful African strategy or to explore opportunities elsewhere. Should the company consolidate its position as market leader or should the 
company endeavor to become a global player? CEO Louw must decide if Shopsmart should enter Nigeria, Africa's most populous state which is enjoying a booming economy as a global oil supplier, or should Shopsmart enter India, a leading emerging market economy with a rapidly expanding middle class. He has been quoted in the press as saying:

"We are trading very well in most parts of Africa and we are looking at oil-rich countries."

"I would rather go to big numbers and play in India, where there are a billion people to deal with --and no supermarkets."

The case will provide students with the opportunity to demonstrate their ability as potential managerial decision-makers. Students will be challenged to weigh the advantages and disadvantages of two potential markets and prompted to make a decision about which market to enter. After completing the case assignment, students will understand the meaning of "emerging market multinational enterprise", "retail internationalization", and "market selection" in India and Africa.

\section{Case Study Introduction}

In early 2004, Dap Louw, the CEO of Shopsmart Holdings, reflected over the many successes his company had enjoyed during the past 25 years. It gave him a tremendous sense of satisfaction. Since the acquisition of eight supermarkets in 1979, Shopsmart had not only captured market share in the South African food retail sector, but also, through aggressive international expansion, the company was now the leading food retailer on the African continent. Despite these impressive accomplishments, his thoughts still returned to a major challenge faced by Shopsmart. Should the company continue its successful expansion strategy by entering new markets in Africa or should it broaden its vision and target growing emerging markets beyond Africa? Opportunities have emerged in two new markets: Nigeria and India. Entrance into Nigeria would be a continuation of a successful African-oriented strategy and, in addition, it would exploit opportunities in Africa's most populous state. Entrance into India would offer huge opportunities as well due to its extremely large population and a rapidly growing middle class who were seeking more retail shopping choices. Louw felt familiar with the shopping behavior of the small, but important, Indian minority in South Africa. South Africans of Indian origin first came to the country in the mid- $19^{\text {th }}$ century. He argued that the behavior of shoppers in India would be similar. Louw was confident that Shopsmart's Board would support his choice since the successful international expansion of the company had been due to his personal vision and execution. He was, however, concerned that the return on investment for overseas operations had come in lower than expected. To his way of thinking, a move into a new market, rather than horizontal growth in existing markets, must bring a higher ROI or the Board would became skeptical regarding further expansion. He also knows that he will receive the blame for failure.

\subsection{Company Background}

In 1979, Capecor entered the food retail sector by acquiring eight Shopsmart supermarkets for R1m (South African Rand). Shopsmart Holdings expanded rapidly and, by the end of 1983, the retailer had opened 21 outlets, mostly in the southern part of South Africa. By 1986, outlets had moved into the central and northern part of the country. Domestic expansion occurred through organic growth and, more dramatically, through acquisitions. In 1991, Shopsmart grew almost six-fold with the acquisition of the national TopGrocer chain of supermarkets. The company now operated 241 outlets in South Africa with a staff of 22,600. In the same year, Shopsmart seized the opportunity to increase its distribution substantially by acquiring Sentraal, a central buying organization which acted as a buying group for 550 owner-managed supermarket members. This acquisition provided Shopsmart with entry into franchising and the ability to compete in smaller convenience markets. In 1997, Shopsmart's penetration of the South African retail markets escalated with the acquisition of BG Bazaars. This strategic expansion added 157 super and hyper size supermarkets and 146 furniture stores to Shopsmart Holdings. Further acquisitions were made in non-food retail, including pharmacies (drugstores), furniture and liquor stores. The focus of this case study, however, will be primarily on food retail.

As a retailer in the mass consumer market, Shopsmart has positioned six branded stores targeting different segments among South African consumers. Shopsmart is the original business. It targets the 
mass middle market and is based on a cost leadership strategy with an emphasis on basic commodities. The TopGrocer and TopGrocer Hyper brands are targeted at more affluent consumers. The TopGrocer stores are usually located in shopping malls. The Hyper stores operate in locations with high population density with product offerings focusing on bulk rather than convenience shopping. Another branded store, Sheba, is a no-frills discounter targeting lower income consumers with a greater penetration of underserved areas in the South African retail market. The BG franchise division has enabled Shopsmart to gain entry into a wide range of mostly smaller convenience markets in suburbs, neighborhoods and rural towns. This brand includes seven types of supermarket and convenience outlets: BG Foods, BG Grocer, BG MiniMart, BG Value, Friendly, 7-Eleven and Priceclub.

\subsection{Internationalization}

"If we can't expose ourselves to risk, we shouldn't be in business. We are cowboys from time to time; we do take risks. But we look at our numbers and are very responsible." (CEO Louw)

After 11 years of operating in South Africa, Shopsmart started international expansion by entering Namibia, a neighboring country. It took another five years before Shopsmart made the next expansion move by entering Zambia in 1995. Dramatic political changes in South Africa necessitated and expedited international expansion. Until 1994, South African companies faced insurmountable obstacles to internationalization. The country was internationally isolated due to comprehensive economic sanctions against the apartheid regime. In 1994, a negotiated settlement was reached and a democracy was established in South Africa. After that, the internationalization process gained momentum. See Exhibit 1. With the acquisition of BG Bazaars in 1997, Shopsmart gained entry into the countries of Swaziland and Botswana by merging BG Bazaars outlets into Shopsmart Holdings. In the same year, Shopsmart also opened an outlet in Maputo, the capital of Mozambique. In 2000, Shopsmart opened outlets in two other African countries, Zimbabwe and Uganda. A year later, Shopsmart entered Malawi and Lesotho. Up to this point international expansion targeted countries within the Southern African continent. These expansion choices were largely understandable given the closer geographical proximity to South Africa; there were strong historical trade and commercial ties between South Africa, the dominant regional economic power, and its neighbors [2]. However, in 2001, Shopsmart moved further afield by opening the first of seven outlets in Egypt. The next year Shop smart entered three more foreign markets. The retailer acquired the French-owned Champion supermarket group in Madagascar, an island nation in the Indian Ocean located east of South Africa. The five shops acquired operated under the Shopsmart brand and included a distribution center. In 2002, Shopsmart entered Mauritius, another island in the Indian Ocean. The retailer made history there by achieving the highest turnover ever recorded for a single opening day of trade. The year ended with an acquisition of three supermarkets and a small distribution center from Score Supermarkets' operations in Tanzania.

Exhibit 1.Shopsmart's expansion in Africa

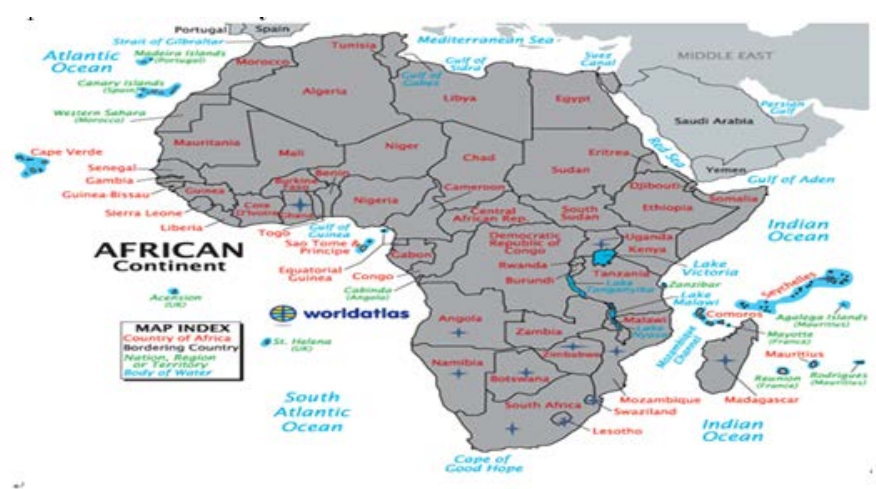

Up to this point, Shopsmart's successful internationalization was a reflection of the company's abilities to implement a standardized strategy and, in doing so, to leverage its intrinsic competencies (6). 
See Exhibit 2. The retailer targeted host countries with underserved and fragmented retail markets. These markets were characterized by small shops, open markets and street vendors, an absence of modern supermarkets and upwardly mobile and aspirational shoppers in an emerging middle class with cosmopolitan tastes (quality, brand awareness but price conscious).

Exhibit 2. Key financial ratios of shopsmart group

\begin{tabular}{llllllll}
\hline & $\mathbf{1 9 9 8}$ & $\mathbf{1 9 9 9}$ & $\mathbf{2 0 0 0}$ & $\mathbf{2 0 0 1}$ & $\mathbf{2 0 0 2}$ & $\mathbf{2 0 0 3}$ & $\mathbf{2 0 0 4}$ \\
\hline Debt: Equity (\%) & 16.0 & 31.0 & 39.8 & 34.8 & 4.3 & 0.1 & 0.1 \\
Liability: Equity & 3.42 & 3.61 & 2.88 & 5.63 & 4.73 & 4.03 & 3.52 \\
Current Ratio & 0.97 & 0.98 & 1.08 & 1.03 & 0.99 & 1.00 & 0.99 \\
Quick Ratio & 0.39 & 0.45 & 0.48 & 0.56 & 0.49 & 0.47 & 0.52 \\
Interest Cover & 5.08 & 1.23 & 5.00 & 4.32 & 6.47 & 6.56 & 21.1 \\
Share Capital & 543,479 & 543,479 & 543,479 & 543,479 & 507,761 & 507,799 & 507,387 \\
Asset Turnover & 14.3 & 12.7 & 12.9 & 12.6 & 17.2 & 19.6 & 17.0 \\
Stock Turnover & 9.7 & 8.3 & 8.8 & 8.3 & 9.1 & 9.3 & 8.2 \\
Operating Margin(\%) & 1.63 & 0.73 & 1.8 & 1.7 & 2.14 & 1.82 & 2.33 \\
ROCE (\%) & 32.6 & 17.8 & 28.7 & 25.7 & 41.00 & 40.9 & 43.4 \\
EPS & 45.7 & 21.0 & 54.1 & 32.3 & 73.7 & 81.4 & 111.7 \\
Dividends per share & 14.4 & 14.0 & 18.0 & 20.5 & 25.5 & 30.5 & 36.0 \\
\hline
\end{tabular}

Sources: Shopsmart: International Market Expansion of an African Retailer

Shopsmart's success is also due to first mover advantage (FMA). Industry analysts have recognized the FMA of Shopsmart in African retail markets: "Africa is where Shopsmart's next growth will come from because it has first entrance advantage over any retailer in Africa. These guys have paid their dues---operating in this continent, and know it like clockwork". (ABSA Asset Management) "Shopsmart has gone through a long journey of African expansion. They paid their school fees. They know what works, and what doesn't. Pick n Pay and other late entrants still need to learn". (Cadiz Financial Services Group). Louw bemoans the lack of data for underdeveloped retail markets in Africa but has proved that his understanding of African consumer behavior in South Africa may be leverage successfully to meet the retail needs of consumers, particularly the emerging middle class, in other African countries.

Shopsmart offers quality goods and brand labels at low costs which make it possible to take market share away from small local outlets. When Shopsmart opened a supermarket in Katutura, a suburb of Windhoek, the capital city of Namibia, the local small shops lost an estimated 50 percent of sales. Subsidiaries of multinational enterprises have the advantage of support from a parent company, while small shops are unable to compete with the lowering of prices and often must exit the market.

Shopsmart's preferred entry mode is to set up wholly owned subsidiaries (WOS), either through acquisitions or greenfield projects. The WOS entry mode was followed in all host countries with the exceptions of Egypt and Mauritius, in which joint ventures (JVs) were utilized. The management policy of Shopsmart is to maintain control over foreign outlets at all levels. That is, standardized brand-based retail supermarkets or convenience outlets are copied in foreign markets, depending on the targeted market segment. Louw explains, "We manage our cost base rigorously at every level and in all aspects of the business." He attributes Shopsmart's success in intensely contested environments to having a focused business plan applied consistently over the years by a stable and experienced management team. Louw prefers a hands-on leadership style based on flexibility. He has an ardent distaste for bureaucracy. He regards himself not as a remote CEO dictating strategy from corporate headquarters and clearly states, "I visit every division at least once a month and I am in our different African operations one to four times a year". Quintus Myburgh, the Chairman of the Board of Capekor, the holding company of Shopsmart, attributes the success of Shopsmart to the drive and vision of Louw. Myburgh has been quoted as saying, "He $\{$ Louw $\}$ has a down-to-earth management style, good people skills, a strong personality, and is very detailed oriented".

Shopsmart's ability to leverage core competencies underpins its successful internationalization. Louw describes the decision to enter African markets as a "hard slog" wherein nearly every aspect of doing 
business has anticipated challenges. The vision of CEO Louw has played a large part in the retailer's international expansion. He states: "There is a saying that retailers can't cross borders. Today it's possible to manage a retail business across the globe. "Louw and Chairman Myburgh like to visit the presidents of African countries they target for expansion. Shopsmart usually lobbies for political support before entering targeted markets by offering to develop sourcing to local suppliers, especially in the agricultural sector, in exchange for government assistance in dealing with regulatory requirements and to secure preferential treatment such as tariff exemptions.

\subsection{Market Choice: India vs Nigeria}

Louw was convinced that Shopsmart has now reached a pivotal point in its internationalization. The retailer has not only successfully entered all the countries in southern Africa, but has also, expanded further by entering Uganda, Tanzania and Egypt. Additionally, it should be noted that the company's expansion into the islands of Madagascar and Mauritius is still regarded as within the African context since these countries are part of the continent's political economy.

CEO Louw now faces a new challenge. Should the company retain its proven African-focused strategy by expanding to other African countries or should Shopsmart target other developing markets outside Africa? Louw was confident that Shopsmart should step-up its game plan and target larger markets with sizeable populations, rapid economic growth rates and a growing middle class of consumers who demand more choices and better quality. He identified two such potential markets in India and Nigeria. Louw viewed India as a perfect fit for Shopsmart's strategy as a low-cost provider targeting markets wherein consumers did not have high disposable income levels and who were looking for good products at low prices. In 2002, CEO Louw dismissed the choice made by its competitor, Pick n Pay, to enter Australia by extolling the opportunities in India, "And before I go to Australia, I would rather go to big numbers and play in India, where here are a billion people to deal with - and no supermarkets". Louw talked about the tremendous opportunities in India and that the market in Mumbai alone was bigger than the whole of South Africa. See Exhibit 3.

Exhibit 3. Economic indicators

\begin{tabular}{cllll}
\hline COUNTRY & \multicolumn{1}{c}{ INDICATOR } & \multicolumn{1}{c}{$\mathbf{2 0 0 1}$} & \multicolumn{1}{c}{ 2002 } & \multicolumn{1}{c}{$\mathbf{2 0 0 3}$} \\
\hline INDIA & GDP $(\$)$ & $\$ 493.9$ bn. & $\$ 523.9$ bn. & $\$ 618.3$ bn. \\
& GDP per capita PPP & $\$ 2176$ & $\$ 2256$ & $\$ 2444$ \\
& GDP growth (annual $\%)$ & $4.8 \%$ & $3.8 \%$ & $7.8 \%$ \\
& Population (Total) & 1.05 bn. & 1.07 bn. & 1.09 bn. \\
NIGERIA & GDP $(\$)$ & $\$ 44.1$ bn. & $\$ 59.1$ bn. & $\$ 67.6$ bn. \\
& GDP per capita PPP & $\$ 2359$ & $\$ 2424$ & 42660 \\
& GDP growth (annual \%) & $4.4 \%$ & $3.7 \%$ & $10.35 \%$ \\
& Population (total) & 125 million & 129 million & 132 million \\
\hline
\end{tabular}

Source: World Bank

The rules for foreign retailers to enter India are quite restrictive[4]. India distinguishes between three categories of foreign retailers. Single brand retailers may only operate with joint venture partners in India. Single brand refers to products sold under the same brand internationally and single brand product retailing covers only products that are branded during manufacturing. The second category is "cash and carry" wholesale retail, i. e. B2B retail in which foreign retailers only sell to local retailers. The wholesale entity may be fully controlled by a foreign company but the retail entity must be fully owned by a local retailer. No investment is allowed for foreign multi-brand retailers, the third category. Large global retailers, such as Wal-Mart and Carrefour, are multi-brand retailers which stock and sell multiple brands directly to consumers (B2C retailers). Shopsmart is a B2C multi-brand retailer.

The mass grocery retail sector in India has more than 12 million retail outlets. However, the modern retail format only has a market share of $0.8 \%$ of total food retail. The sector consists of traditional, independent owner-managed stores as well as more modern format, outlet shops. The traditional sector comprises kirana (mom and pop) stores which sell the basic necessities such as groceries, and may be in 
the form of street carts, pavement stores, kiosks and weekly markets. Kirana stores are unique to India and have been in existence for a long time. In 2004, the more modern sector included a variety of outlets: 2,276 supermarkets, 35 hypermarkets, 522 discount stores and 3,500 convenience stores. Well established local retailers include Panteloon, Subhikstra, RPG, Ad Ofitya, Reliance, Nigrini Franchise, and others. A large foreign retailer, Metro from Germany, has already entered India in 2003 to set up "cash and carry" wholesale stores. India, as a prominent emerging market (with a large population, fast economic growth rate and a growing middle class), has already been featured on the expansion plans of global retailers such as Tesco, Wal-Mart and Carrefour. Negotiations are currently in progress to ease the restrictions on these multi-brand retailers in opening outlets in India. At this stage, however, Shopsmart's only option is to enter as a B2B wholesale retailer without participation in the more lucrative $\mathrm{B} 2 \mathrm{C}$ retail market.

In India, there is considerable opposition from both the traditional and organized retail sector against the entry of large foreign retailers into the Indian market[5]. The traditional sector fears that modern retailers will crowd them out of the market. This sentiment is shared by small retailers (and their trade associations), farmers, middle men, open market workers and hawkers. Organized labor has led strikes against retailers (both foreign and domestic). Opposition to modern retailers has been fueled by the decision of regulators in some Indian states to allow retailers to bypass wholesale markets and to buy directly from farmers or even start their own contract farming. Opposition to the growth of the modern food retail sector in India often raises the argument that foreign retailers will not only push small retailers out of the market, but also, that they will have a negative effect on employment. The traditional retail sector employs $7.2 \%$ of the total workforce in Indian.

Another argument, raised by Kishore Biyane, CEO of the Indian retailer Big Bazaar, is that the modern Indian retail sector is still an infant industry. He argues that this sector should not be given away to foreign players while it is too young to compete on a level playing field. Biyane pointed out that the average Walmart store (200,000 sq. ft.) is four times the size of his flagship Big Bazaar store. This opposition has resulted in the politicization of issues regarding retail liberalization and foreign direct investment in the retail sector. Specific state-by-state legislation in India regulates many aspects of high-value retail, including business hours of operation and restrictions on corporate power in the creation of production networks. The granting of business licenses is slow due to bureaucratic "red tape" and operating licenses may be withdrawn for political reasons. Under pressure from labor unions, the state of Kerala closed down 10 Reliance Fresh Outlets (an Indian retailer). Contract farming by retailers was also prohibited to protect small farmers and open market operators. As a result, Reliance scrapped plans for an extension of 200 supermarkets and related infrastructure development. A store manager of Metro, the German retailer, explains the difficult retail environment in India: "Not only is there social resistance against retail as a form. There is resistance against foreigners. If you are a multinational company, it is tougher then when you are an Indian company".

Despite obstacles, India offers tremendous opportunity for multinationals to enter the retail market before maturity will be reached. The immense size of the Indian population and the rapid expansion of the middle class due to income growth, particularly in urban areas, are at the root of this positive outlook. The rise in disposable income and increasing urbanization means that retailers which provide high value processed food will experience strong growth. Large retailers may leverage efficiency and scale economics to provide lower prices, wider product choices and well-known brand names to these consumers. With contract farming, large retailers will also take market share away from wet or open markets at which Indian consumers traditionally shop.

Louw is well aware of the challenges facing a foreign retailer in India. He has identified three major challenges. First, domestic competition may be more resilient than in other markets Shopsmart has previously entered. Second, consumer behavior is less focused on buying at supermarkets, preferring fresh markets or small neighborhood shops. India has approximately twelve million kiranas. Shopping in the informal sector is well entrenched. The kirana shops, in the unorganized sector, offer many benefits to consumers such as easy credit and delivery service. Switching cost may be high since Indian consumers often lack storage space which inhibits bulk shopping offered by modern retailers. Louw recognized in 2005 that 70 percent of Indian consumers preferred to shop in the informal sector, while only 30 percent preferred to shop in supermarkets. Third, foreign direct investment (FDI) regulations and import tariffs pose higher barriers for foreign retailers to operate in India. Louw contended that Shopsmart would only succeed if it could capture 50 percent of the market. 
Likewise, Shopsmart regards Nigeria as a promising market for future expansion. CEO Louw stated: "We are trading very well in most parts of Africa and we are looking at oil-rich countries". The high oil prices in recent years have boosted the Nigerian economy and GDP growth, which in turn, heightened consumer confidence and non-essential spending on food items. Nominal domestic demand was $\$ 77.42$ bn in 2004, up from $\$ 31.52$ bn in 2000. Personal disposable income doubled in the same period. The economy was driven by private consumption which contributed 73.9 percent to GDP in 2004. This exceeded even the 65.95 percent of consumption as a percentage of GDP in South Africa. Nigeria's dynamic economic growth coupled with its large population will stimulate demand for the opening of new grocery outlets across the country. While a majority of the population still lives in poverty, demand is driven by the more affluent minority and the growing middle class of consumers. The improved economic conditions have affected the number of working women who prefer "one stop" convenience offered by supermarkets to open markets wherein every purchase is an individual, time-consuming barter. Nigerian shoppers are aspirational, price conscious and demand good quality.

With Shopsmart's experience in African markets and its success in targeting middle class shoppers, the retailer is well positioned to take advantage of the opportunities in Nigeria. The firm's proven record of hard work to establish its brand, to build solid customer loyalty and to extend store numbers appears to be a good fit for Nigerian markets. The retail food sector in Nigeria has been described as fragmented and underserved. Supermarkets only command about 2 percent share of total food sales, while traditional wet markets and small convenient stores account for 41 percent and 57 percent of food sales, respectively. The only local retailer is Park n Shop with only 20 outlets in Lagos. However, Park n Shop needs to address its image problems, caused by a series of highly publicized run-ins with customs authorities for stocking smuggled goods. At this time, no foreign retailers are operating in Nigeria but the country has a receptive business environment.

Other South African companies have successfully entered Nigeria. MTN, a mobile network operator, entered the Nigerian telecommunication market in 2000. MTN was first to market, invested in a backbone infrastructure, and designed an effective marketing campaign that resonated with consumers. MTN now has market share in Nigeria. The opportunity for Shopsmart to enter Nigeria before its competitors and to gain a strong foothold in the country before others appears to be very positive at this time. At this stage, global retailers do not have Nigeria on their radar due to the high risk exposure of the country. Louw, however, is aware of serious challenges facing a foreign retailer in Nigeria. The country has high import barriers for food products and available sites/facilities in which to open outlets are scarce. However, Louw believes that Shopsmart's learning experience in Africa has shown that exceptions to trade barriers may be negotiated with the government. He also believes that his company's success in developing sourcing opportunities for local suppliers elsewhere in African markets may work well in Nigeria. The lack of sites/facilities may prove to be a positive in that it provides an opportunity for Shopsmart to acquire the best locations for its retail outlets. Like many African countries, Nigeria has an inadequate infrastructure and high tariff barriers, but Louw relies on Shopsmart's proven experience, elsewhere in Africa, to develop a supply chain in Nigeria through local sourcing and imports. Louw argues that the strong Rand furnishes Shopsmart with an advantage for making property investments in potential African markets. For example, The Palms Mall in Lagos, currently under construction, offers a highly desirable, potential site for a Shopsmart outlet in Nigeria's largest port city. This is leverage to first movers and creates costly barriers to all late entrants. All-in-all, the situation in Nigeria fits Shopsmart's proven strategy of setting up a WOS, inevitable through a greenfield investment, since acquisition of Park $\mathrm{n}$ Shop is not in the cards. Like South Africa, Nigeria has democratized its government. The civil war has ended. Like many African countries, civil strife caused by ethnic divisions remains an issue in Nigeria. The country is in a positive change trend, but the long term prospects remain uncertain. Louw, however, was optimistic that the opportunities offered by the rising disposable incomes of the growing urban middle class to shop in modern retail stores will trump the risks of potential political instability.

\section{Case Overview}

Shopsmart, a South African food retailer, faced an important decision in the company's expansion plans. To date, the company has been successful in expanding to neighboring countries, and then further afield, 
by entering other African countries. The choice facing Shopsmart is whether to continue its successful African strategy or to explore opportunities elsewhere. Should the company consolidate its position as market leader or should the company endeavor to become a global player? CEO Dap Louw must decide if Shopsmart should enter Nigeria, Africa's most populous state which is enjoying a booming economy as a global oil supplier, or should Shopsmart enter India, a leading emerging market economy with a rapidly expanding middle class.

The case is based upon secondary materials such as company reports, financial statements, media reports and other forms of library research. Shopsmart is a fictional name used for an actual retail multinational enterprise with a home base in South Africa.

The case will provide students with the opportunity to demonstrate their ability as potential managerial decision-makers. Students will be challenged to weigh the advantages and disadvantages of two potential markets and prompted to make a decision about which market to enter. After completing the case assignment, students will understand the meaning of "emerging market multinational enterprise", "retail internationalization", and "market selection" in India and Africa.

\section{$5 \quad$ Discussion Question}

Shopsmart faced a difficult choice of either entering India or Nigeria. Which market should the company pick? Which factors will influence an entry decision? What are the advantages and disadvantages of the Indian and Nigerian markets? Which market should Shopsmart choose to achieve long-term and sustainable profitability? Provide detailed justification for your market choice.

\section{$6 \quad$ Teaching Plan}

A SWOT analysis may be a suitable tool to analyze and to compare the suitability of the Indian versus the Nigerian market for Shopsmart. See Exhibit A. The instructor may ask students to list the relevant factors in the case which may influence Shopsmart's choice. Students may be asked to explain the nature and relevance of the factors. To demonstrate the applicability of these factors, the instructor should prompt students to fit the factors into the SWOT framework on the white board. Once the SWOT framework has been completed, students should compare the attractiveness of the Indian and Nigerian markets by prioritizing the factors for the two markets. For example, positive values for Strengths and Opportunities $(+1$ to +3$)$, and negative values for Weaknesses and Threats $(-1$ to 3 ). Once values have been designed, the class may be asked to make a choice between India and Nigeria by showing of hands. Allow about 10 minutes of debate between the pro-India and the pro-Nigeria groups.

Exhibit A. SWOT analysis of retail sectors of Nigeria and India

\begin{tabular}{|c|c|c|}
\hline Swot & Nigeria & India \\
\hline Strengths & $\begin{array}{l}\text { - Transition to civilian government } \\
\text { enhances FDI attractiveness } \\
\text { - Large \& growing population will } \\
\text { stimulate demand for opening of new } \\
\text { grocery outlets across country } \\
\text { - Rising disposable income of middle } \\
\text { class and growing number of working } \\
\text { women stimulate demand for "one-stop" } \\
\text { convenient shopping }\end{array}$ & $\begin{array}{l}\text { - Developing retail sector with } \\
\text { expansion across all formats \& all regions } \\
\text { in the country } \\
\text { - Growing middle class consumers with } \\
\text { demand for product variety }\end{array}$ \\
\hline Weaknesses & $\begin{array}{l}\text { - Selling power of retailers limited by } \\
\text { price as major determinant of purchasing } \\
\text { decisions } \\
\text { - } \quad \text { Inadequate infrastructure inhibits } \\
\text { expansion \& distribution } \\
\text { - Import tariffs a barrier to global }\end{array}$ & $\begin{array}{l}\text { - Widespread poverty and regional } \\
\text { diversity are impediments to growth } \\
\text { - } \quad \text { Inadequate infrastructure requires } \\
\text { substantial investment in supply chains } \\
\text { before new stores can be opened } \\
\text { - } \quad \text { Retail FDI restricted to single brand }\end{array}$ \\
\hline
\end{tabular}




\begin{tabular}{|c|c|c|}
\hline & sourcing & $\begin{array}{l}\text { "cash \& carry" (B2B) } \\
\text { - Excessive regulatory regime } \\
\end{array}$ \\
\hline Opportunities & $\begin{array}{l}\text { - First mover advantage: no major } \\
\text { foreign competitors; local SMEs \& open } \\
\text { markets offer little competition } \\
\text { - Shopsmart may leverage African } \\
\text { experience to negotiating deals and } \\
\text { securing tariff exemptions } \\
\text { - Opportunities to develop local } \\
\text { sourcing (legitimacy building) } \\
\text { - Opportunities to secure sites and for } \\
\text { real estate developments (shopping } \\
\text { malls) } \\
\text { - Government policy to reduce oil } \\
\text { dependency should benefit retail sector }\end{array}$ & $\begin{array}{l}\text { - Good opportunities for large retail } \\
\text { MNEs that may offer low prices } \\
\text { - Busy lifestyles of urban consumers } \\
\text { favor convenience offered by mass retail } \\
\text { - Lower income rural segment poorly } \\
\text { served and will become desirable target } \\
\text { market as urban markets reach maturity }\end{array}$ \\
\hline Threats & $\begin{array}{l}\text { - Re-emergence of military } \\
\text { intervention in politics } \\
\text { - Civil strife caused by ethnic divisions } \\
\text { could negatively affect economic boom \& } \\
\text { retail expansion }\end{array}$ & $\begin{array}{l}\text { - } \quad \text { Metro, a major retailer from } \\
\text { Germany, has already entered India } \\
\text { - } \quad \text { Growing number of Indian } \\
\text { supermarkets will be resilient competitors } \\
\text { - } \quad \text { Many retail stakeholders (farmers, } \\
\text { market operators, Kirana stores, labor } \\
\text { unions, politicians) view mass retail as an } \\
\text { infant industry and oppose retail FDI } \\
\text { - Switching cost may be high for } \\
\text { consumers due to services provided by } \\
\text { Kirana shops }\end{array}$ \\
\hline
\end{tabular}

Source: Business Monitor International, Food \& Drink Reports

In terms of strengths, India has a slight advantage due to its larger population and middle class. Both markets have similar weaknesses typical of the business environments of developing countries: infrastructure problems, consumer preference for low prices, and regulatory burdens. For Shopsmart, the restriction on $\mathrm{B} 2 \mathrm{C}$ retail in India, makes Nigeria a better choice for long term profitability. In terms of opportunities, Nigeria also has an edge since Shoprite will enjoy first mover advantage. The firm's knowledge of the African business environment also provides considerable leveraging power in negotiating business deals. The threat situation in Nigeria has the potential of problems related to political instability. The threats in India are more immediate and more directly relevant to the retail sector. The opposition to retail FDI is not only pronounced, but also, has become a political issue. An argument may be made that the retail environment in India poses more threats to a potential Shopsmart entry than the environment in Nigeria. Taking the SWOT analysis as a whole, an inference may be made that Shopsmart should stick to its African-oriented strategy and choose Nigeria as an expansion target.

\section{Epilogue}

Shopsmart entered India in 2004. In 2006, Louw still regarded the firm's prospects in India as good, with current sales growth and customer growth at 70 percent and 25 percent, respectively. Two years later, Louw cautioned that Shopsmart had suffered large losses and that India would take at least twoand-a-half years to become profitable subject to improvement in the regulatory environment.

In 2008, Shopsmart exited India.

According to Louw, the preference by Indian consumers for bargained, rather than for advertised pricing meant that Shopsmart did not achieve desired market share. The resulting unprofitability made the exit from India inevitable. Louw reported that the initial liberalization of India's FDI regime, which permitted 51 percent FDI in single-brand products, opened the window for the entry of foreign retailers. 
However, the exclusion from the B2C market (retailers sold a variety of brands under one roof) inhibited profit growth. According to Louw, retailers such as Shopsmart which rely on global sourcing, India's high tariff barriers on imports and other regulatory burdens imposed severe transaction costs which devaluated the value proposition to unacceptable levels. Such a regime proved unsustainable for Shopsmart and led to its exit.

Shopsmart entered Nigeria in 2005 and currently operates 7 retail outlets in Nigeria.

\section{References}

1. N. Alexander and M. De Lira e Silva, "Emerging markets and the internationalization of retailing: The Brazilian experience," International Journal of Retail \& Distribution Management, vol. 30, no.6, pp. 300-314, 2002

2. N. Alexander, M. Rhodes, and H. Myers, "A gravitational model of international retail market selection," International Marketing Review, vol. 28, no. 2, pp.183-200, 2011.

3. C. Bianci, "Retail internationalization from emerging markets: Case study evidence from Chile," International Marketing Review, vol. 26, no.2, pp. 221-243, 2009.

4. A. Chari, and T. C. A. Madhav Raghavan, "Foreign direct investment in India's retail bazaar: Opportunities and challenges," The World Economy, vol. 35, no. 1, pp.79-90, 2012.

5. M. Franz, "The role of resistance in a retail production network: Protests against supermarkets in India," Singapore Journal of Tropical Geography, vol. 31, pp. 317-329, 2010.

6. C. Okeahalam, and S. Woods, S, "Financing internationalization: A case study of an African retail transnational corporation," Journal of Economic Geography, vol. 9, pp. 511-537, 2009.

7. D. D. Weatherspoon, D. and T. Reardon, T. "The rise of supermarkets in Africa: Implications for agrifood systems and the rural poor," Development Policy Review, vol. 21, no. 3, pp. 333-355, 2003. 